\title{
The role of regional products in preserving traditional farming landscapes in the context of development of peripheral regions - Lubelskie Province, Eastern Poland
}

\author{
Ewa Skowronek ${ }^{1}$, Teresa Brzezińska-Wójcik ${ }^{1}$, Andrzej Stasiak², Andrzej Tucki ${ }^{1, *}$
}

\author{
${ }^{1}$ Maria Curie-Skłodowska University, Faculty of Earth Sciences and Spatial Management, Department of Regional \\ Geography and Tourism, Poland \\ 2 University of Łódź, Faculty of Geographical Sciences, Department of Geography of Recreation, Poland \\ * Corresponding author: andrzejtucki1@gmail.com
}

\begin{abstract}
The article presents the functioning of traditional farming landscapes in Eastern Poland, using the example of Lubelskie Province. This peripheral region, situated on the border of the European Union, demonstrates how the development of tourism, food tourism in particular, based on local crops and regional foodstuffs, helps to protect and promote local heritage and, at the same time, gain additional financial resources for its inhabitants. With a view to the aims set in the paper, the authors investigated the perception of the Lublin Region's image as regards the predominant features of the natural and socio-economic environment. Moreover, they analysed the recognisability of the regional products and dishes among people from outside the province, who have visited it for tourism purposes. The research material was collected during international and Polish tourism fairs held in five largest Polish cities. The researchers collected 493 questionnaires, 220 of which underwent a detailed analysis. The study shows that the leading functions of Lubelskie Province include agriculture and tourism. The particular form of tourism that should be developed in the region is food tourism and related products due to the natural features and landscape assets. The conclusions drawn from the respondents' answers as well as the query of strategic documents and promotional campaigns allowed the researchers to outline further directions as regards using traditional farming landscapes with the aim of development of the region. It appears that centuries-old forms of farming and methods of food production, resulting from the region's history and natural conditions, may determine recognisability, build a brand based on the place of origin concept, and influence the socio-economic situation of the area, preserving traditional landscapes at the same time.
\end{abstract}

\section{KEYWORDS}

rural areas; peripheral regions; traditional farming landscapes; food tourism; place of origin

Received: 25 February 2019

Accepted: 13 January 2020

Published online: 13 March 2020

Skowronek, E., Brzezińska-Wójcik, T., Stasiak, A., Tucki, A. (2020): The role of regional products in preserving traditional farming landscapes in the context of development of peripheral regions - Lubelskie Province, Eastern Poland. AUC Geographica 55(1), 49-65 https://doi.org/10.14712/23361980.2020.1

(C) 2019 The Authors. This is an open-access article distributed under the terms of the Creative Commons Attribution License (http://creativecommons.org/licenses/by/4.0). 


\section{Introduction}

The subject matter of this paper is the functioning of traditional farming landscapes in Eastern Poland, Lubelskie Province. It is a peripheral region located to region located on the border of the European Union, Ukraine, and Belarus. Centuries-old farming forms and food production methods associated with the natural environment and the history of the area have been maintained here.

As shown by many researchers (e.g. Fischer et al. 2012; Brown, Kothari 2011; Selfa et al. 2010; Skowronek et al. 2005), traditional farming landscapes are typical of many areas where farming and animal breeding practices have not changed significantly over the centuries. These areas can be easily distinguished due to their characteristic socio-economic features: 1) the predominance of small-size fields; 2) extensive farming; 3) orientation of production towards satisfying one's own needs or the needs of local markets; 4) cultivation of traditional crops and farming methods (Fischer et al. 2012).

This type of farming results, among other things, in a unique culinary heritage of the region. Many publications demonstrate that currently support and promotion thereof has a significant influence on the economy and the image of peripheral regions with large tourism potential (Ivanova et al. 2014; Bessiére, Tibere 2013; Borowska 2010; Sims 2009; Hall et al. (eds.) 2003; Bessiére 1998), one of which is the region discussed herein (Bronisz et al. 2017).

Furthermore, regional dishes can become attractive to tourists, since they reflect the "typical features" of a specific area/region (Bessiere 1998; Urry 1990).

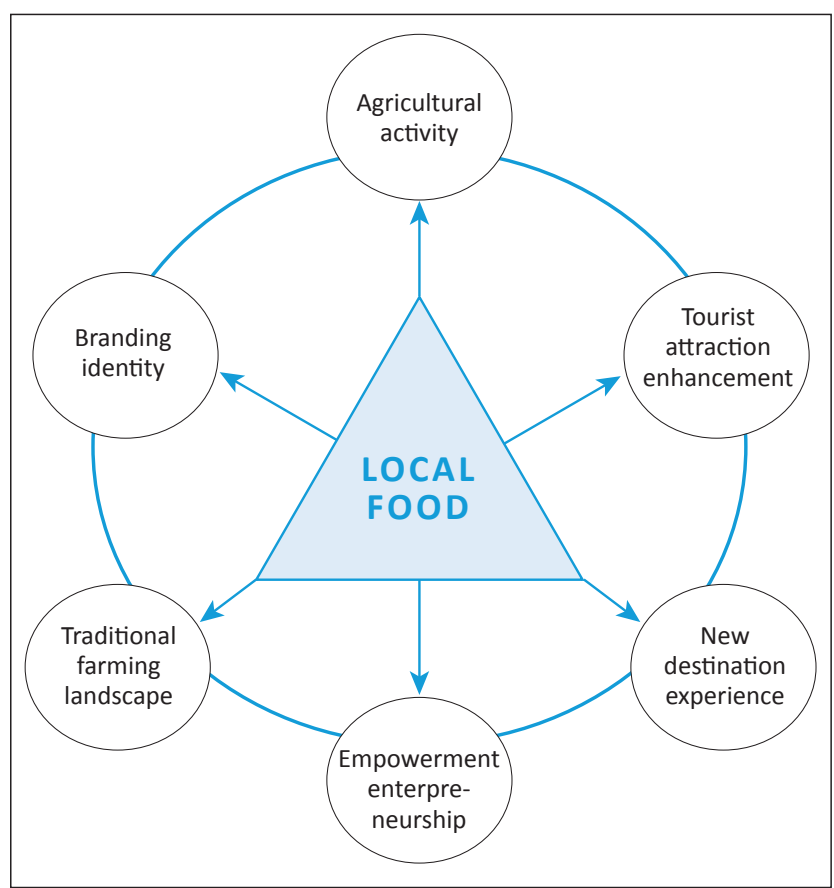

Fig. 1 Contribution of local food to regional development; own analysis based on Gerrie et al. (2003).
Local food is rarely the main reason for visiting a destination and is most often considered part of the overall experience of the destination (Hjalager, Richards 2002). Yet, it may become one of the most important attractions, as tourists are increasingly searching for authentic experiences and alternative forms of tourism (Hall et al. (eds.) 2003; Hjalager, Richards 2002; Crouch, Ritchie 1999).

Therefore, the present article is in line with the research on traditional farming landscapes. Similar to other publications (e.g. Špulerová et al. 2017; Fischer et al. 2012), it touches upon the problem of the exceptional value of such landscapes as well as the ways of their protection and preservation in the future. On the other hand, it concerns the issues of the development of tourism, including culinary aspects (food tourism, culinary tourism, gastronomic tourism) in areas with agricultural heritage/traditional farming landscapes. The topic has been discussed before, for instance by Kowalczyk (2016); Richards (2015); Jansen-Verbeke, McKercher (2013); Vafadari (2013).

Moreover, an important aspect discussed in the article is territorial marketing - building the image of the region, creating a place brand (e.g. Lai et al. 2017; Spilková, Fialová 2013; Lin et al. 2011; Hankinson 2004), and in particular building a region brand based on the place of origin concept or authenticity.

As demonstrated by the literature, food is regarded as a reflection of the culture of the country/region and its inhabitants. It is therefore a product - an attraction at the destination that can be simultaneously used as a marketing tool (e.g. Okumus, Cetin 2018; Lin et al. 2011; Cohen, Avieli 2004; Hall et al. (eds.) 2003; Long (ed.) 2003; Hjalager, Richards 2002; Richards 2002; Wolf 2002) (Figure 1).

There are many examples from different countries/regions where practical associations have been created between food, tourism, and regional development with the aim of the development and promotion of regional culinary products (Boniface 2003; Hall et al. (eds.) 2003; Richards 2002; Scarpato 2002; Macdonald 2001). The development of culinary tourism based on local food and wine has been described by Hall et al. (eds.) (2003) in Australia and New Zealand, and by Corigliano (2002) and Bessiere (1998) in regions of France (e.g. Burgundy, Champaign, Bordeaux) and Italy (Tuscany).

This study emphasises an important aspect of territorial marketing targeted at building the region's brand in relation to the place of origin concept. It is based on a transfer of the image, connotations, and stereotypes related to a given place (country, region, city) onto a specific product/products, which significantly determines consumer's behaviour and preferences.

The influence of the place of origin on increasing the value of the product and on the consumers' motivations and behaviours has been the object of numerous studies and scientific works conducted in 
a number of countries. They regard a wide range of products, including drinks and foods, e.g. wine (Bruwer, Lesschaeve 2012), beer (Lentz et al. 2006), cheese (Marcoz et al. 2016), or pork (Lorenz et al. 2015).

To date, the place of origin concept has rarely been discussed in the context of tourism development in an area (e.g. Charters et al. 2017). In Poland, it was not until recently that several provinces started to consciously use this conception in promotional activities (Milewska et al. 2017; Stasiak 2015) - e.g. Lubelskie Province (Bekier-Jaworska, Bochenek 2014).

The main aim of the study is to present the relationships between the traditional agricultural landscape of Lublin Province, the current use of its resources, and the possibilities of preservation thereof in the future, with the example of activities related to the development of culinary tourism. This objective is supported by the following detailed research tasks: 1) identification/description of the resources of traditional agricultural landscapes in terms of development of tourism, including the culinary aspect; 2 ) presentation of actions undertaken for recognisability of the Lublin Province in relation to the place of origin concept; 3) recognition of the perception of the Lublin region by tourists from other Provinces; 4) determination of the degree of recognisability of regional products and dishes originating from the Province across Poland; 5) assessment of the potential of the use of traditional agricultural landscapes in the light of strategic documents; 6 ) indication of activities to be undertaken aimed at the use of the traditional agricultural landscape of the region.

\section{Characteristics of the study area}

Lubelskie Province, the third largest and the eighth most populated province in Poland, is at the lowest level of economic development in Poland and the European Union (Michon 2017). Its structure is dominated by the agricultural function, which has been developed over centuries and based on the favourable natural conditions. Arable lands account for $70 \%$, while forests represent approximately $23 \%$ of the whole area (Rolnictwo... 2017).

\subsection{Natural determinants of the functioning of agricultural landscapes}

Lubelskie Province covers a varied and visually attractive area between the Vistula River and the eastern border of the country. It features three natural regions, whose diversity is reflected by landscape variety. The northern and north-eastern part of the province is occupied by lowland areas - it is a land of pastures, marshes, peatbogs, and lakes. It consists of South Podlasie Plain and Western Polesie (Figure 2). The absolute heights in the lowland usually range from 160 to $200 \mathrm{~m}$ a.s.l., and the denivelations do not exceed
$30 \mathrm{~m}$. In Polesie, these values are 155-165 m a.s.l. and $10 \mathrm{~m}$, respectively (Świeca, Brzezińska-Wójcik 2009). The plains were built from quaternary river sands and lake clays, which transformed into luvisoils, podsolic, and alluvial soils, respectively (Turski et al. 2008). Moreover, vast areas are covered by peatbogs. The presence of the only karst lakes in Poland is a characteristic feature of this land. Meadows and pastures prevail in the agricultural use of the area, but there are also fields of rye, barley, corn, and potatoes (Bański 2010). Cattle and horses (including thoroughbreds and Arabian stallions) are also bred in the region.

The central part of the area is occupied by macro-regions - Lublin Upland, Roztocze, Volhynian Polesie, and Volhynian Upland - built from Mesozoic and Cenozoic carbonate-siliceous rocks partly covered with loess. Their characteristic features include large denivelations (differences in height/altitude) of up to $100 \mathrm{~m}$ and areas with the greatest number of loess gorges in Europe, near Kazimierz Dolny and Szczebrzeszyn (11 km per $\left.1 \mathrm{~km}^{2}\right)$ (Świeca, Brzezińska-Wójcik 2009). Rendzic leptosols are typical of carbonate-siliceous rocks, whereas brown earth and luvisols, as well as chernozems are characteristic for of loess-covered rocks (Turski et al. 2008). The nearly woodless upland is covered with a patchwork of arable fields. The whole area is grown with wheat, sugar beet, and rape crops. The plants grown in Lublin Upland also include hops, herbs, roses, some vegetables (e.g. cabbage, garden beets, carrots) and fruit (e.g. apples, raspberries, strawberries). In Volhynian Polesie, there are plantations of potatoes and barley, in Volhynian Upland - edible pulses (broad beans, kidney beans, peas), and in Roztocze - fields of buckwheat, tobacco, onion, and beans (Bański 2010). Animal breeding in the whole upland area is dominated by swine, and by poultry (hens) in Volhynian Polesie.

The southern part of the province is located within the limits of Sandomierz Basin. It is formed by plains and uplands with denivelations of 10-40 m. The typical elevations in the uplands built of quaternary dune sands are 240-250 metres a.s.l., while in the uplands formed from Miocene clays covered with quaternary sands and clays, they range from 195 to $250 \mathrm{~m}$ a.s.l. (Świeca, Brzezińska-Wójcik 2009). The majority of soils in this area are podzolic soils and luvisols (Turski et al. 2008), with potatoes, buckwheat, rye and linen crops (Bański 2010). The landscape is dominated by vast forest complexes - Janowskie Forests and Solska Forest, with characteristic natural resources, i.e. mushrooms and fruit (cranberries, crowberries).

\subsection{Specific socio-economic traits of the region}

In most areas of Lubelskie Province, the traditional agricultural function co-occurs with specific socio-economic conditions, typical of peripheral regions. In the literature, such areas are described 
as problematic, marginal, or poorly developed economically and requiring support for development processes (Mazur et al. 2015). Their characteristic features include a low level of socio-economic development, especially as regards its socio-demographic aspect (e.g. weak population density and urbanization rates, depopulation processes), and the cultural and political-administrative aspect. They are characterised by poor prospects for improvement, including enhancement of the living standards. As regards the spatial criteria, the areas in question are difficult to reach by transport and are located far away from major economic and development centres (Miszczuk 2010).

Around 52\% of Lubelskie Province population are country dwellers. About $80 \%$ of all farms are small, ranging from 1 to 10 hectares. The fragmentation and small area of the farms do not ensure achievement of satisfactory production results. Thus, most farmers run business activity only to satisfy their own needs. As a result, large numbers of young people leave the province, which leads to the depopulation of rural areas (Flaga 2018). The population density in the rural areas of Lubelskie Province is on average 47 persons $/ \mathrm{km}^{2}$ (in Poland - 53 persons $/ \mathrm{km}^{2}$ ); the smallest density was recorded in its borderland area and southern part (Powierzchnia... 2018). The dynamics of area development is considerably slowed down by the absence of major industrial centres, peripheral location, and the close proximity of even more poorly developing borderland regions of Ukraine and Belarus.

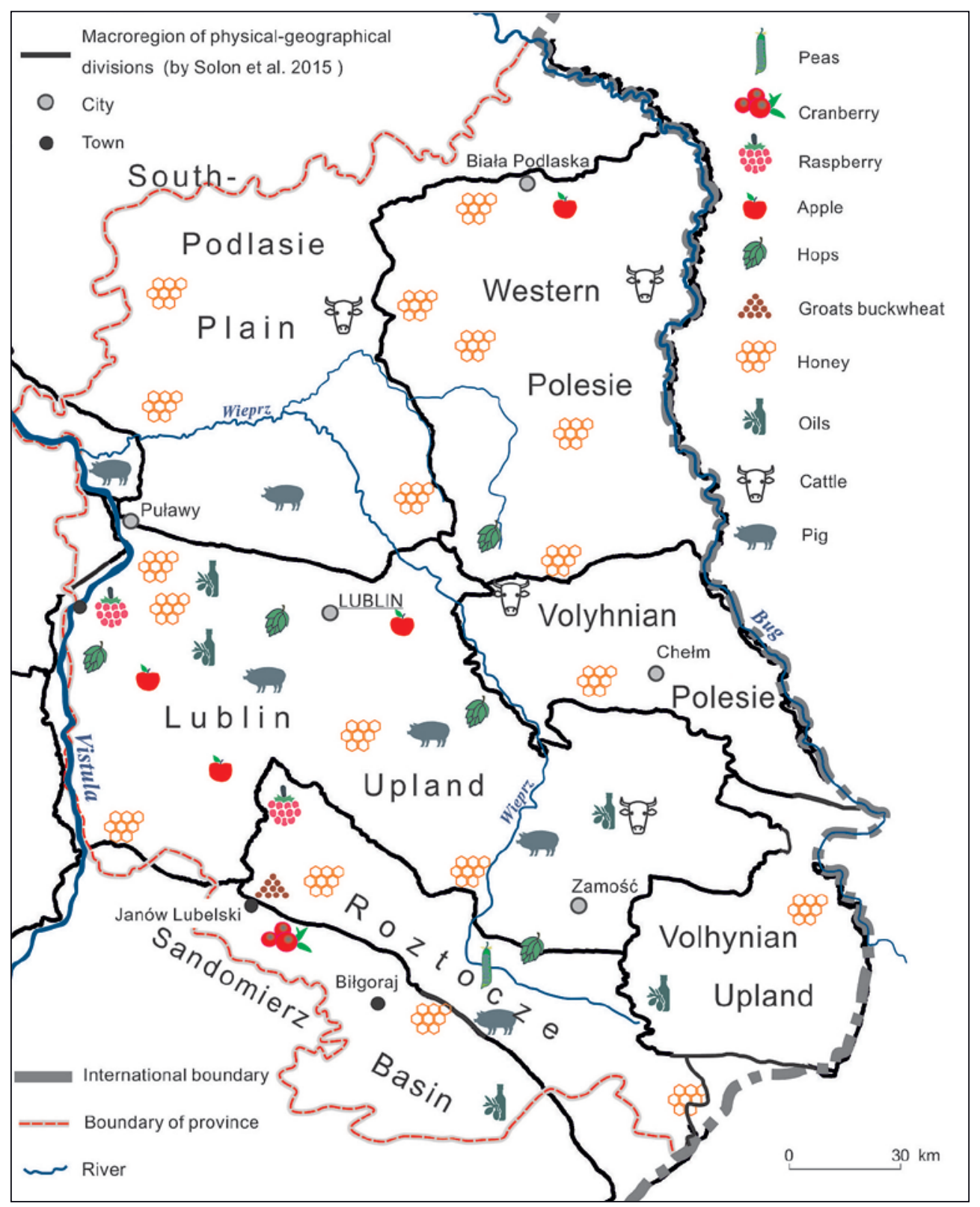

Fig. 2 Major crops and leading trends in animal breeding in Lubelskie Province with respect to physical-geographical regions. Source: Authors. 


\subsection{Touristic resources in terms of development of tourism}

Poorly developed industry and the predominance of extensive agricultural production in Lubelskie Province lead to a situation where, next to the services sector, chances for some improvement of the economic situation are sought in tourism (Bronisz et al. 2017). Its growth is based on the natural and cultural assets of the region.

The most valuable elements of the natural environment in the province are taken under protection in the form two International Biosphere Reserves (MAB) - the "Western Polesie" and "Roztocze", two national parks - Roztoczański and Poleski, as well as 17 landscape parks, 17 areas of protected landscape,
87 nature reserves, and nearly 1300 monuments of nature (Figure 3).

The province's rich cultural resources are rooted in its multinational and multi-denominational history. Due to the borderland location at different periods, the area was inhabited by Russians, Jews, Germans, Lithuanians, Italians, Armenians, the Dutch, Scots, Austrians, the French, English, Greeks, and Tatars. Despite the stormy history, many elements of the tangible and intangible cultural heritage have been preserved (Skowronek et al. 2006). The largest group of objects includes historical buildings performing different functions (residential, religious, economic, and industrial) as well as public utility buildings and small architecture structures, e.g. roadside chapels, saints' figures, crosses, etc. (Figure 4). There are also some interesting

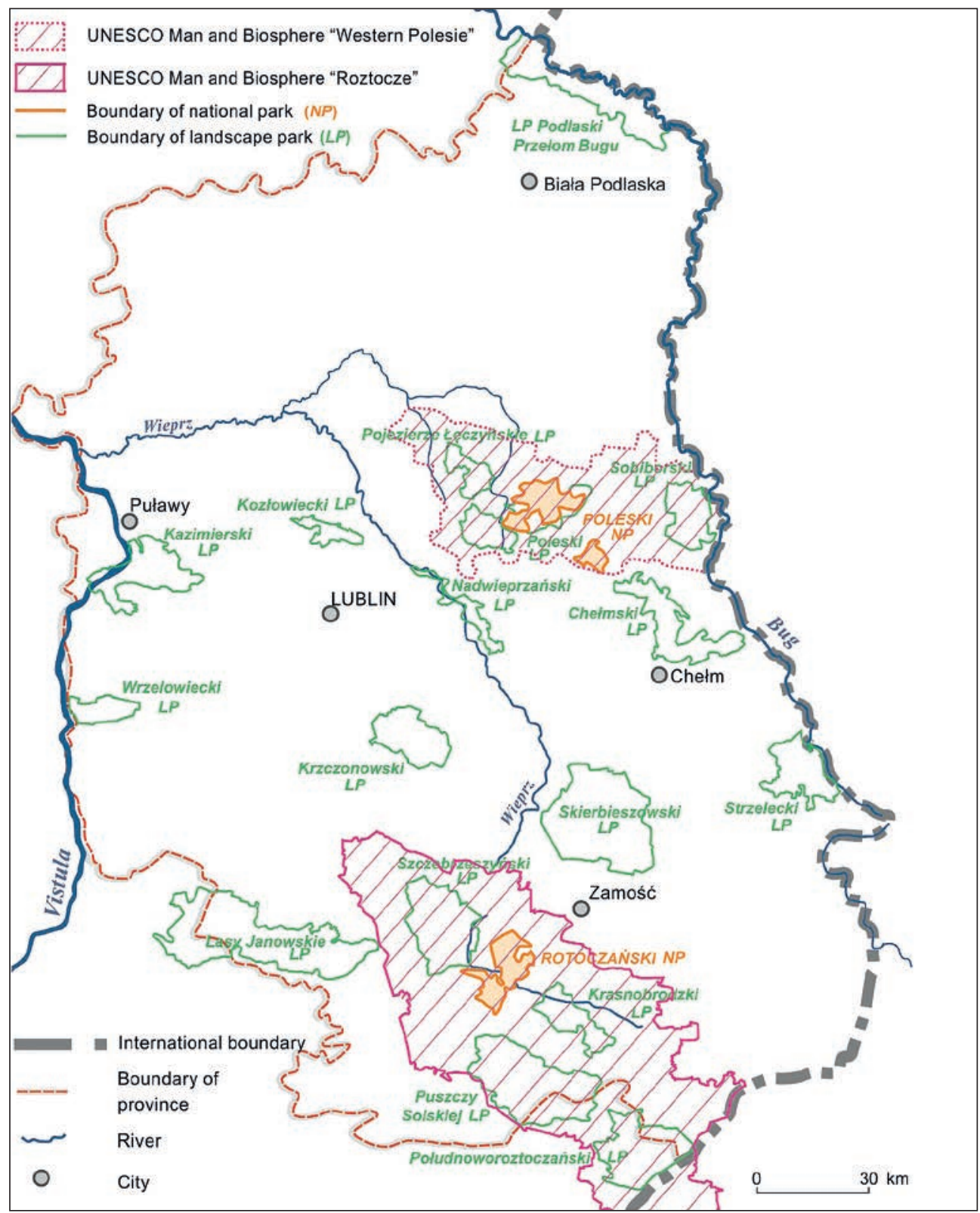

Fig. 3 Most valuable elements of the natural environment in Lubelskie Province. Source: Authors. 


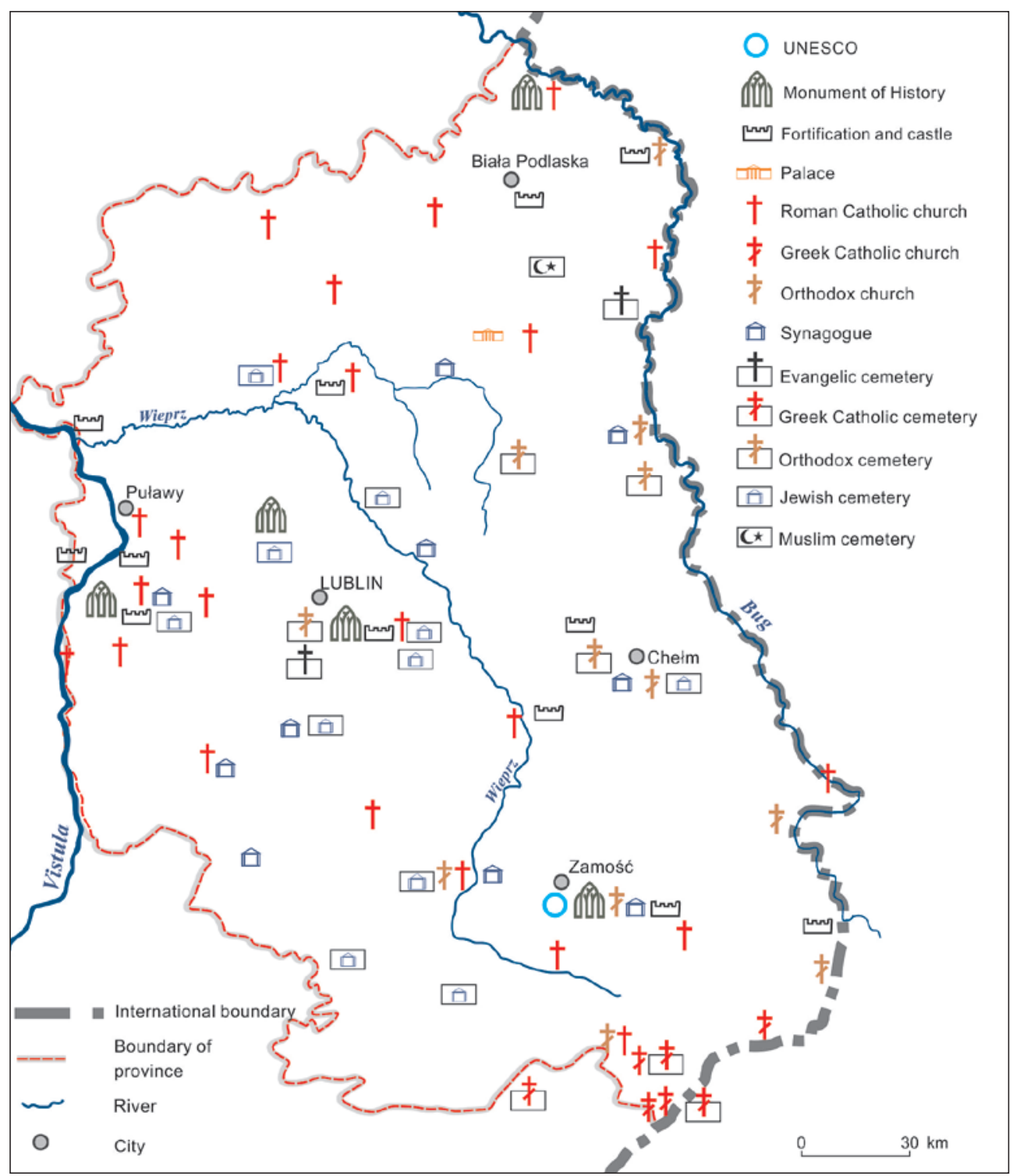

Fig. 4 Most valuable elements of the cultural heritage of Lubelskie Province.

Source: Authors.

old urban and rural spatial layouts (Szczęsna, Gawrysiak 2009). The most precious elements of the cultural heritage in the region have been appreciated and taken under international and national protection. The old Town in Zamość has been placed on the UNESCO World Heritage List (1992). Moreover, five monuments of history have been established: Kazimierz Dolny, Kozłówka - a palace and park complex, Lublin - a historical architectonic and urban complex, Janów Podlaski a horse stud, and Zamość - a historical urban complex surrounded by 19th c. fortifications (Figure 4).

Besides some spectacular examples of material culture, the province can boast of noteworthy elements of intangible heritage, such as rich folklore, traditions and customs, as well as local cuisine. The unique features of the latter are strictly connected with the multiculturality of the inhabitants and the diversity of original recipes, ingredients, and cooking methods (Orłowski 2016).

\section{Research methods}

In order to achieve their established goals, the authors used primary and secondary materials. The secondary sources included Central Statistical Office data, scientific publications regarding the geographical environment of the area, traditional rural landscapes, and territorial marketing. Moreover, the authors collected and used publications and websites presenting the promotional campaigns of Lubelskie Province. In this aspect, the prospects of tourism development, including culinary tourism with respect to traditional farming landscapes of the region were analysed. Secondary materials were obtained using the preliminary research method.

Primary materials were collected during a field study with the use of participant observation and the diagnostic survey method. The field observations were conducted in the summer seasons of 2017 and 

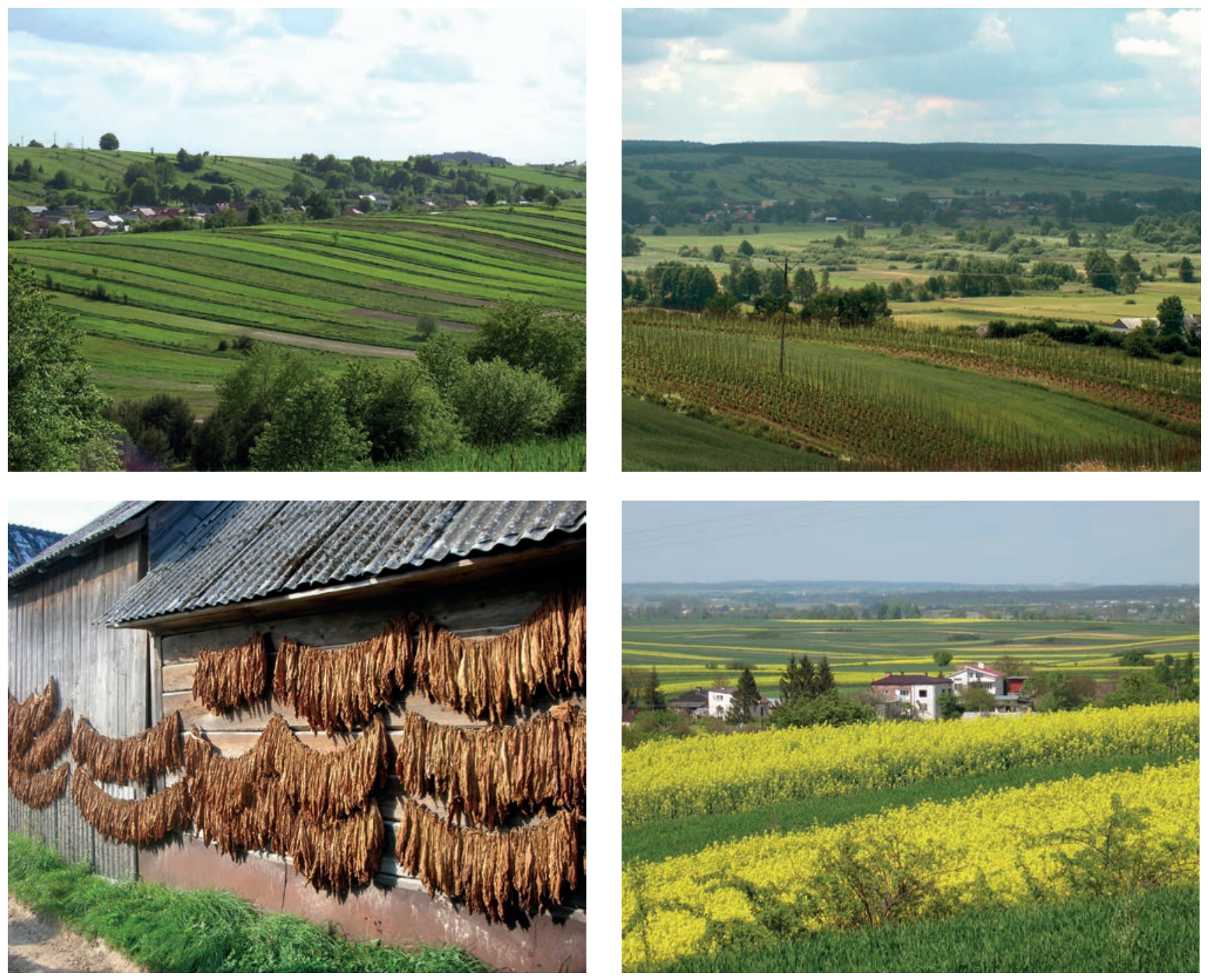

Fig. 5-8 Traditional agricultural landscapes and crops in Lubelskie Province (photo: authors, 2016).

Tab. 1 Respondent profile.

\begin{tabular}{|c|c|c|c|c|c|c|c|c|c|c|c|c|}
\hline features & \multicolumn{12}{|c|}{ characteristics of the sample } \\
\hline \multirow{2}{*}{$\begin{array}{l}\text { gender } \\
{[\%]}\end{array}$} & \multicolumn{5}{|l|}{ males } & \multicolumn{7}{|c|}{ females } \\
\hline & \multicolumn{5}{|l|}{41.8} & \multicolumn{7}{|l|}{58.2} \\
\hline \multirow{2}{*}{$\begin{array}{l}\text { age } \\
\text { [\%] }\end{array}$} & \multicolumn{2}{|l|}{ under 20} & $21-30$ & \multicolumn{2}{|c|}{$31-40$} & \multicolumn{2}{|l|}{$41-50$} & $51-60$ & \multicolumn{2}{|c|}{$61-70$} & \multicolumn{2}{|c|}{ over 70} \\
\hline & \multicolumn{2}{|l|}{6.4} & 33.2 & \multicolumn{2}{|c|}{23.2} & \multicolumn{2}{|l|}{13.6} & 12.7 & \multicolumn{2}{|c|}{8.6} & \multicolumn{2}{|l|}{1.8} \\
\hline \multirow{2}{*}{$\begin{array}{l}\text { education } \\
\text { [\%] }\end{array}$} & \multicolumn{2}{|c|}{ elementary } & middle school & \multicolumn{2}{|c|}{ vocational } & \multicolumn{2}{|c|}{ secondary } & college & \multicolumn{2}{|c|}{ higher vocational } & \multicolumn{2}{|c|}{ higher MA } \\
\hline & \multicolumn{2}{|l|}{0.5} & 1.8 & \multicolumn{2}{|l|}{3.2} & \multicolumn{2}{|l|}{20.9} & 9.1 & \multicolumn{2}{|c|}{16.8} & \multicolumn{2}{|c|}{47.3} \\
\hline \multirow{2}{*}{$\begin{array}{l}\text { place of } \\
\text { residence } \\
\text { [\%] }\end{array}$} & country & & $\begin{array}{l}\text { town with fewer } \\
\text { than } 20.000 \\
\text { inhabitants }\end{array}$ & $\begin{array}{l}\text { tow } \\
20- \\
\text { inha }\end{array}$ & & $\begin{array}{l}\text { city wit| } \\
51-100 \\
\text { inhabita }\end{array}$ & & $\begin{array}{l}\text { city with } \\
101-200.000 \\
\text { inhabitants }\end{array}$ & & 0.000 & $\begin{array}{l}\text { city } \\
\text { over } \\
\text { inha }\end{array}$ & .000 \\
\hline & 8.6 & & 2.4 & 5.6 & & 10.5 & & 7.4 & 19 & & 45.6 & \\
\hline $\begin{array}{l}\text { province } \\
\text { [\%] }\end{array}$ & $\begin{array}{l}n \\
0 \\
i\end{array}$ & 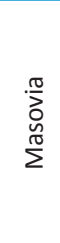 & $\frac{\frac{\pi}{\sqrt{\omega}}}{\sqrt{\tilde{n}}}$ & 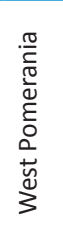 & 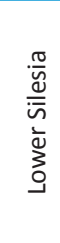 & 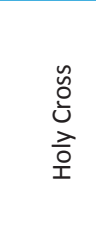 & 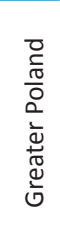 & 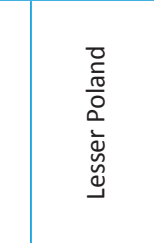 & 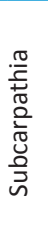 & 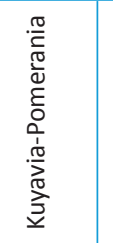 & $\begin{array}{l}\hat{N} \\
\hat{0} \\
\overrightarrow{3}\end{array}$ & $\begin{array}{l}\frac{0}{\bar{y}} \\
\frac{\pi}{0} \\
\frac{0}{0}\end{array}$ \\
\hline & 38.6 & 19.5 & 14.1 & 9.1 & 6.4 & 5.0 & 1.8 & 1.6 & 0.9 & 0.5 & 0.5 & 0.5 \\
\hline
\end{tabular}

Source: Authors based on the own calculations and the questionnaire survey. 
2018. The questionnaire-based survey was carried out between November 2017 and June 2018 during international and domestic tourism fairs in Warsaw, Wrocław, Łódź, Katowice, and Szczecin. It included respondents from outside Lubelskie Province, who filled out 493 survey questionnaires. A detailed analysis involved 220 questionnaires (44.6\%) selected based on the respondents' presence in the region and the tourism-oriented purpose of travel. Thus, the sample consisted of tourists from outside the province, which fitted the concept followed in the article. The empirical data that was collected was processed by means of statistical and cartographic methods.

\subsection{Characteristics of respondents}

The group of the respondents consisted of 220 tourists from outside Lubelskie Province, who declared a tourist purpose of their visit and were staying in the Lubelskie Region at that time. A small majority of them $(58.2 \%)$ were women. As for the age structure, most respondents were aged 21-40 (56.4\%). The majority of them had completed higher $(47.0 \%)$ and secondary (20.6\%) education.

Importantly, the respondents came from 12 provinces (except Warmia-Mazuria, Opole, and Pomerania Provinces), despite the fact that the data was collected only in cities that organised tourism fairs. This is connected with the respondents' place of origin. The majority of people came from Łódź (38.6\%), Masovia (19.5\%), Silesia (14.1\%), West Pomerania (9.1\%), Lower Silesia (6.4\%), and Holy Cross (5.0\%) Provinces. They were mostly inhabitants of large cities populated by more than 500,000 people $(45.6 \%)$ and smaller cities, inhabited by $201,000-500,000$ residents $(19.6 \%)$ (Table 1$)$.

\section{Traditional farming landscapes of the Lublin region as the potential to build the region's image and recognisability}

With reference to secondary resources (publications and internet websites on promotional campaigns of Lublin Province), the activities of Lublin self-government for creation of the image and recognisability of the region through agricultural landscapes and local food products were analysed. Noteworthy, Lublin self-government was the first authority in Poland to recognise this potential of development of the region. Particular attention was paid to the regional products which were defined, after Winawer and Wujec (2010), as those "whose quality is noticeably higher than average and inseparable from their place of origin and local methods of production" (Adamczuk 2013). That strategy was possible to implement due to the specific features of local farming and products, considered to be healthy, ecological, and based on the region's tradition. Thus, the brand that started to be developed was based on the place of origin.

\subsection{The place of origin concept}

The place of origin concept assumes transferring the image, associations, and stereotypes regarding a given region onto a specific product, thus having an effect on the consumers' behaviours and preferences. The bond between the product and the area may be so strong that products become the region's brand (Andéhn, Berg 2011; Usunier 2006; Peterson, Jolibert 1995; Schooler 1965).

The place of origin may be indicated by the name of the product (e.g., if it contains geographical adjectives), information about the product placed on the wrapping or label, the appearance of the product (packaging), marketing communications (advertisements, PR), or certificates. The products most commonly promoted via the place of origin effect include foodstuffs, especially regional and traditional. In the European Union, they are protected by a special legal protection system, and registered under one of three schemes: Protected Geographical Indication (PGI), Protected Designation of Origin (PDO), and Traditional Speciality Guaranteed (TSG) products.

The Protected Geographical Indication (PGI) scheme protects products whose names include the proper name of the region where the whole technological process takes place (extracting ingredients, production, preparing the product for sale). Moreover, the quality of the product and its reputation are strictly related to the fact that it comes from a specific area (e.g. Parma ham - prosciutto de Parma).

The Protected Designation of Origin (PDO) scheme protects products whose connection with the place of origin is weaker, but at least one of the three stages of the production process takes place in this area. Their quality may result from both natural features (climate, vegetation, land relief, type of soil) and anthropogenic factors (inhabitants' skills, methods and traditions of production, local know-how) (e.g. Gouda cheese).

The Traditional Speciality Guaranteed (TSG) scheme protects products that bear special names emphasizing their unique features and are produced from traditional food resources. They may be made from traditional ingredients or produced in a traditional way (e.g. Naples pizza - pizza napoletana) (Milewska et al. 2017).

To sum up, marking a product's place of origin makes it unique and guarantees its high quality provided by the local tradition. Market-wise, it becomes more attractive, purchased more willingly, and competitive. On the other hand, the high quality of such products, clients' satisfaction, and their positive opinions promote the region from which the products originate. In this way, they create, strengthen, and establish a positive image of the area. Thus, there is mutual reinforcement of two brands: the brand of the product 


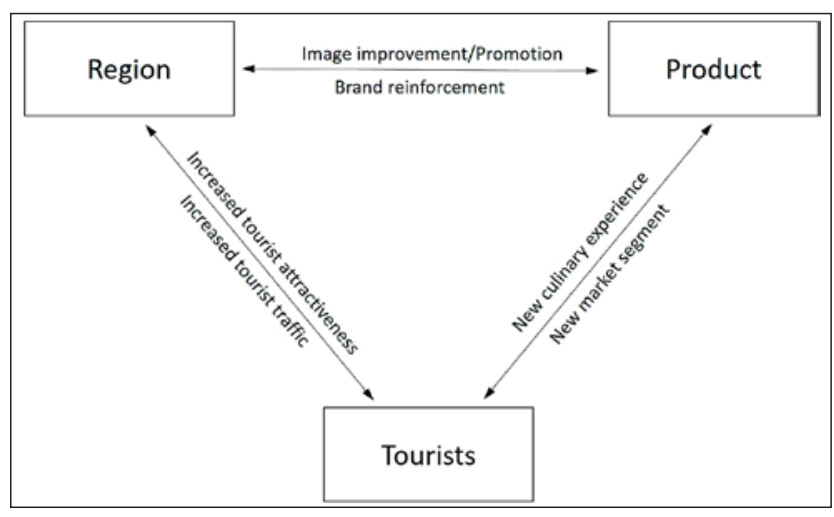

Fig. 9 Place of origin concept - relationships between the region, the product, and the tourists. Source: A. Stasiak.

through the reputation of the place and the brand of the place through the reputation of the product.

The same relationship occurs between tourist regions and local food products. The customers include tourists who buy regional products while visiting a given area. Local specialties, strongly identified with the visited region and its landscape, provide tourists with new experience. It may be purely culinary (eating products in an attractive landscape) or it may have a wider cultural dimension and involve the possibility of discovering the history and the contemporary life of the region, modern farming methods, and ways of making food. As a result, the visit becomes richer, more exciting, and long remembered.

The offer of traditional products increases the region's attractiveness, improves its image, or increases the number of tourists. Theoretically, we can assume a certain model of relationships between the region, the product, and the tourists (Figure 9).

This article is the first attempt to describe the relationships presented in the model, using the example of Lubelskie Province. This administrative region was the first in Poland to implement consciously and purposefully the place of origin strategy in the promotion of food and tourism products.

\subsection{Activities increasing the recognisability of Lubelskie Province}

Since 2008, several national campaigns have been launched, e.g. "Lubelskie is great for the weekend" (2008), "Lubelskie - turn off the stress, turn on the power!" (2009), "Lubelskie - may the moment last!" (2010), "Lubelskie. Taste life!" (2011), "Lubelskie brand” (2011), "Lubelszczyzna flavours" (2011-2012), "Lubelskie - for a while or longer" (2014), "Lubelskie. The best because it's ours!" (2015), and "The force is in us!" (2016). Through those campaigns, the authorities of the region encouraged people to buy and consume goods produced in Lubelskie Province. Moreover, the activities mentioned above were to help identify the region with the high culture of taste by highlighting the image of the Lublin Region as a land of ecological food. The campaigns also emphasised that it was not only about tasting a wide variety of foods, but also "tasting" culture, taking advantage of beautiful nature, and indulging in one's passions. The campaigns cost over 2.5 million Euro and in greater part were sponsored by the European Union. They involved distributing billboards all over Poland, broadcasting commercials on national and private TV channels (national and regional), launching on-line campaigns on popular information portals and Facebook, radio campaigns (nationwide and regional), press campaigns (in nation-wide and regional magazines), and promotion during Polish and international tourism fairs and in selected airlines using Lublin airport (https://www.lubelskie .pl/kampanie-promocyjne; Skoczylas 2012).

The commercials broadcast as part of two campaigns won prizes at a number of international CIFFT festivals (International Committee of Tourism Film Festivals). In 2010, the spot entitled "Lubelskie - may the moment last!" won six awards at the CIFFT festivals in Poland, Romania, Slovenia, Russia, the Czech Republic, and Austria (the Grand Prix). In 2014, another spot, entitled "Lubelskie - for a while or longer", was appreciated at the CIFFT festivals in Berlin, Riga, and Warsaw.

The promotional campaigns were run in the media (radio, television, press, Internet) in all the provinces in Poland, and large-format billboards and citylights could be found in the largest Polish cities: Warsaw, Gdansk, Szczecin, Poznań, Krakow, Katowice, Łódź, Wrocław, and Rzeszów.

The promotional activity was also run abroad, e.g. through airlines in cities where passengers can fly directly from Lublin (e.g. Dublin, Stockholm, Glasgow, Brussels). Economic commercials and advertising boards were placed in mass media, e.g. on BBC News, on TV channels in Europe, Asia, and Pacific, and the Middle East; commercials promoting the region were broadcast during international CIFFT festivals; events promoting brand regional products were organised in Brussels (2011 and 2012).

Regional foodstuffs have been successively introduced onto the Polish List of Traditional Products supervised by the Ministry of Agriculture and Rural Development. Currently, with its 208 products, Lubelskie Province comes third on the list (https://www .gov.pl/rolnictwo/lista-produktow-tradycyjnych12). In 2014, a regional specialty - Lublin cebularz (onion pie) was registered under the Protected Geographical Indication (PGI) scheme.

\section{Analysis of the perception of Lubelskie Province}

To achieve the goals adopted in the study, the perception of the image of the Lublin Region was investigated 
with respect to the predominant features of the natural and socio-economic environment and the recognisability of its regional products and foods was analysed. On this basis, the effectiveness of the promotional campaigns across the country was assessed. This knowledge allowed establishment of the direction of possible activities aimed at taking advantage of the traditional farming landscape of the region.

\subsection{Perception of the major features of the socio-economic and natural environments of Lublin Province}

The analysis of the region's image started from a question the tourists were asked about their direct associations with Lubelskie Province. The respondents pointed mainly to its rich history and multicultural heritage (16.6\%), well-developed agriculture (14.9\%), tourist attractiveness (14.8\%), diversified and well-preserved nature $(13.6 \%)$, and hospitality $(11.4 \%)$. Less frequently, they mentioned features associated with the peripheral character of the region, e.g. the peripheral location (9.9\%), poorly developed industry $(16.9 \%)$, backwardness and poverty $(1.8 \%)$ (Figure 10).

Based on the responses, it can be concluded that the majority of tourists perceive the region positively. It should be emphasised that the respondents indicated resources promoting the development of tourism (rich history and multicultural heritage; tourist attractiveness; diverse, well-preserved nature; hospitality) as the most recognisable; these observations accounted for $56.4 \%$ of all responses. Together with the opinions on the well-developed agriculture in the region, they constituted as much as $71.3 \%$ of all responses. Therefore, it can be assumed that, besides the agricultural function, the tourist function should be developed in the province.

Next, the opinions were verified. The respondents were asked to evaluate the socio-economic situation of Lubelskie Province on a 1-5 scale. It turned out that most tourists described it as good (53.6\%) and average $(27.3 \%)$, although in fact Lubelskie Province is one of the poorest regions of the European Union as

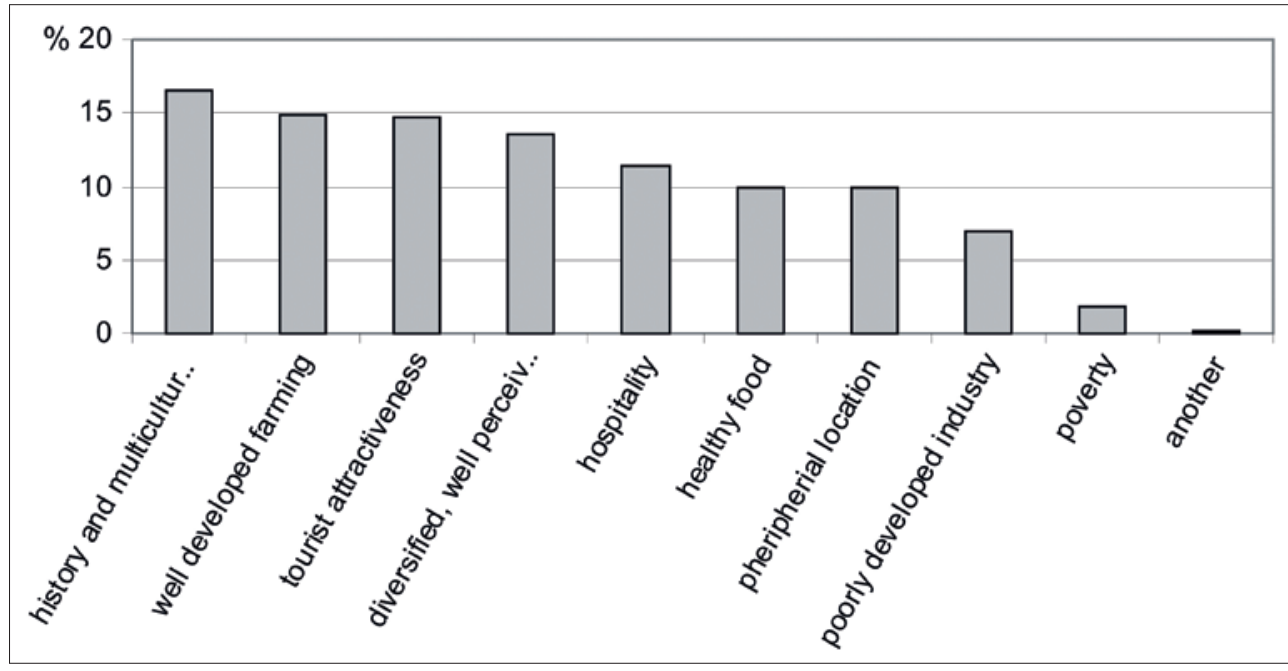

Fig. 10 Respondents' general connotations with Lubelskie Province.

Source: Authors, based on own calculations and the questionnaire survey.

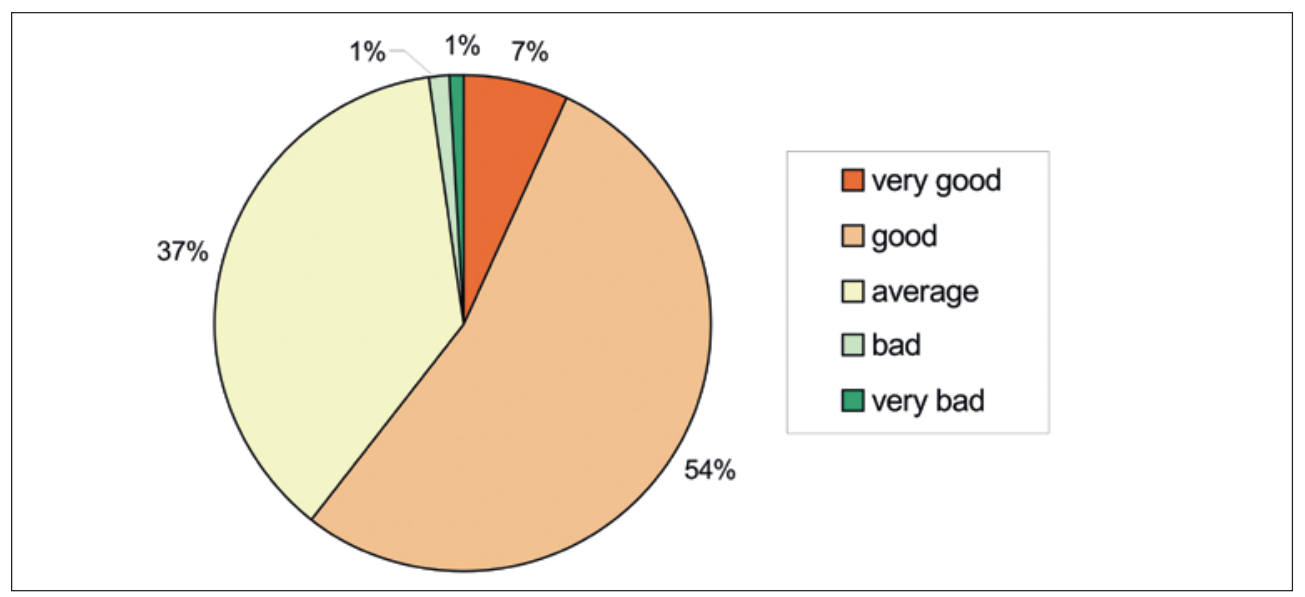

Fig. 11 Respondents' evaluation of the socio-economic situation of Lubelskie Province. Source: Authors, based on own calculations and the questionnaire survey. 


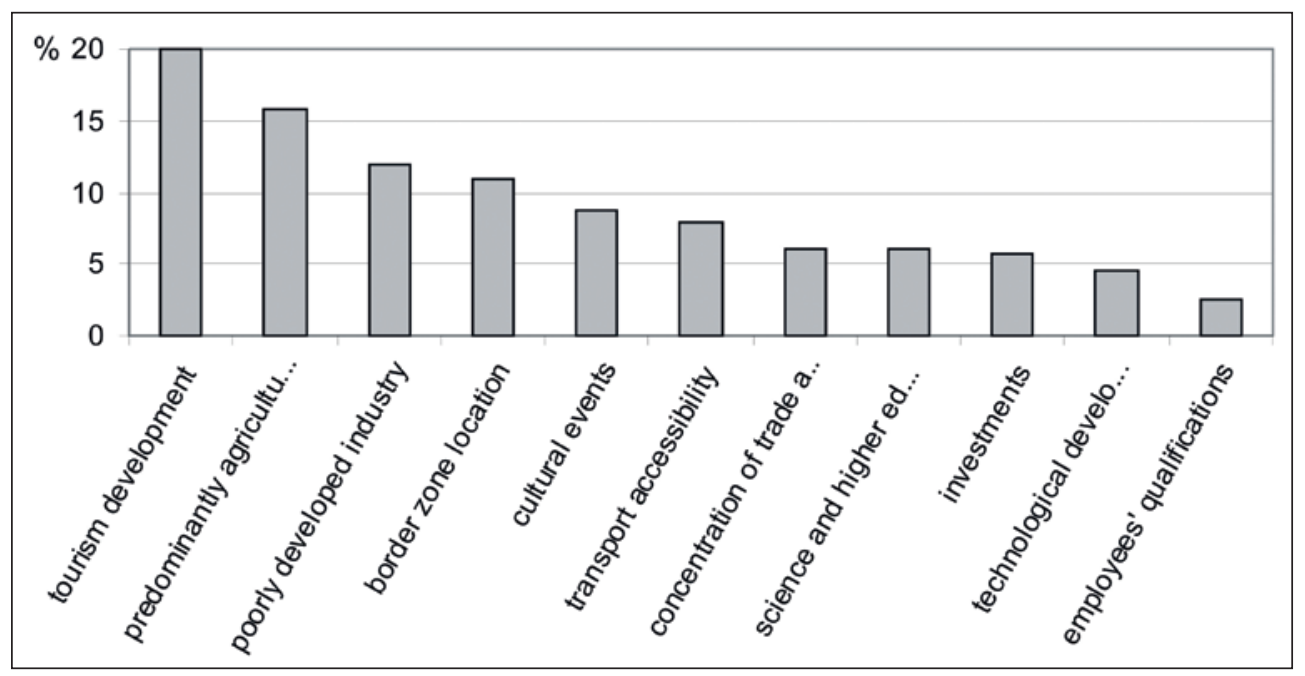

Fig. 12 Causes of the current socio-economic situation of Lubelskie Province perceived by the respondents. Source: Authors, based on own calculations and the questionnaire survey.

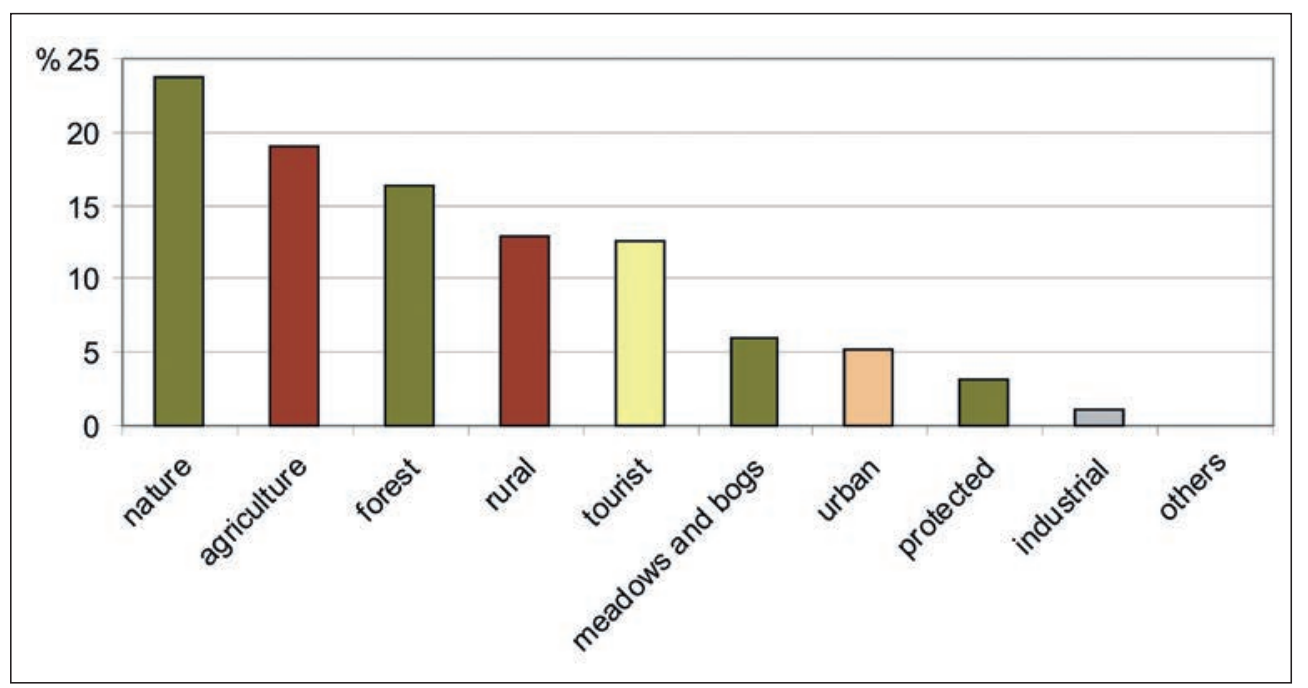

Fig. 13 Landscape types associated by the respondents with Lubelskie Province. Source: Authors, based on own calculations and the questionnaire survey.

regards GNP. Very few respondents said that the situation is bad $(1.4 \%)$ or very bad $(0.9 \%)$ (Figure 11 ).

When asked to indicate the factor which they believed was the cause of the current socio-economic situation of the province, the respondents usually pointed to the development of tourism (20.0\% of all indications), the predominantly agricultural function (15.8\%), the poorly developed industry (12.0\%), and the border zone location (10.9\%) (Figure 12).

In the next part of the study, the tourists indicated the types of landscape that they associated with Lubelskie Province. Most respondents associated the area with natural (23.7\%) and farming (19.0\%) landscapes, woodlands (16.4\%) as well as rural (12.9\%) and tourist (12.5\%) landscapes (Figure 13). As many as $90.5 \%$ believed that the anthropogenic transformation of the region's natural environment was insignificant or average.
All the responses presented herein allow us to conclude that although tourists recognize the peripheral character and the economic weaknesses of the region, their evaluation is still positive. In their opinion, the most important factors determining the province's development are tourism and agriculture. Interestingly, the economic shortcomings are viewed as advantages, guaranteeing a high-quality natural environment, only slightly transformed by people (e.g. well-preserved nature, absence of industry, healthy food). Such an approach may have an influence of the respondents' trust in the food products coming from the Lublin Region, which are considered healthy, high quality, and based on tradition that fits into the place of origin concept. The high-quality natural environment as a development factor in peripheral regions was emphasised by e.g. Olechnicka (2004). 


\subsection{Recognisability of regional products and foodstuffs from Lubelskie Province}

As mentioned before, products may create, strengthen, and consolidate the positive image of an area. Hence, the knowledge of local products and dishes that Polish tourists staying in Lubelskie Province had was investigated.

First, the respondents were asked whether they were familiar with the regional dishes or products from Lubelskie Province. Over 1/4 of them (26.8\%) provided a positive response. Next, they were asked to give examples of regional food. The analysis of the responses shows that the best-known regional products include Lublin onion cake (cebularz) (25\% of responses), gryczak/Biłgoraj pieróg (9.4\%), vorschmack (a kind of goulash soup), and rape honey (3.1\% each). The respondents also mentioned potato dumplings (kartacz cake), traditional dumplings, kulebiak pie (stuffed pastry), regional breads and oils, raspberry tincture (malinówka), sękacz pie (a "branched-tree" cake), drop scones (racuchy), Polish potato pie (kartoflak), bałabuchy pie, and pickled apples (Figure 14).

Except two (kartacz cake and bałabuchy pie), all the products or dishes mentioned by the respondents can be found on the List of Traditional Products (a register kept by the Ministry of Agriculture and Rural Development). In 2014, Lublin onion cake (cebularz) was registered under the Protected Geographical Indication (PGI) scheme.

Next, all the respondents were shown a list of products and dishes and asked to choose those that, in their opinion, were originally from Lubelskie Province. The results point to a relatively good knowledge of the Lublin region food among the respondents. It is confirmed by the average number of indications (over 3) for each of them. Tourists most often pointed to onion cake/cebularz (13.6\%) honey, (11.9\%), traditional dumplings (9.6\%), sękacz (6.9\%), gryczak/

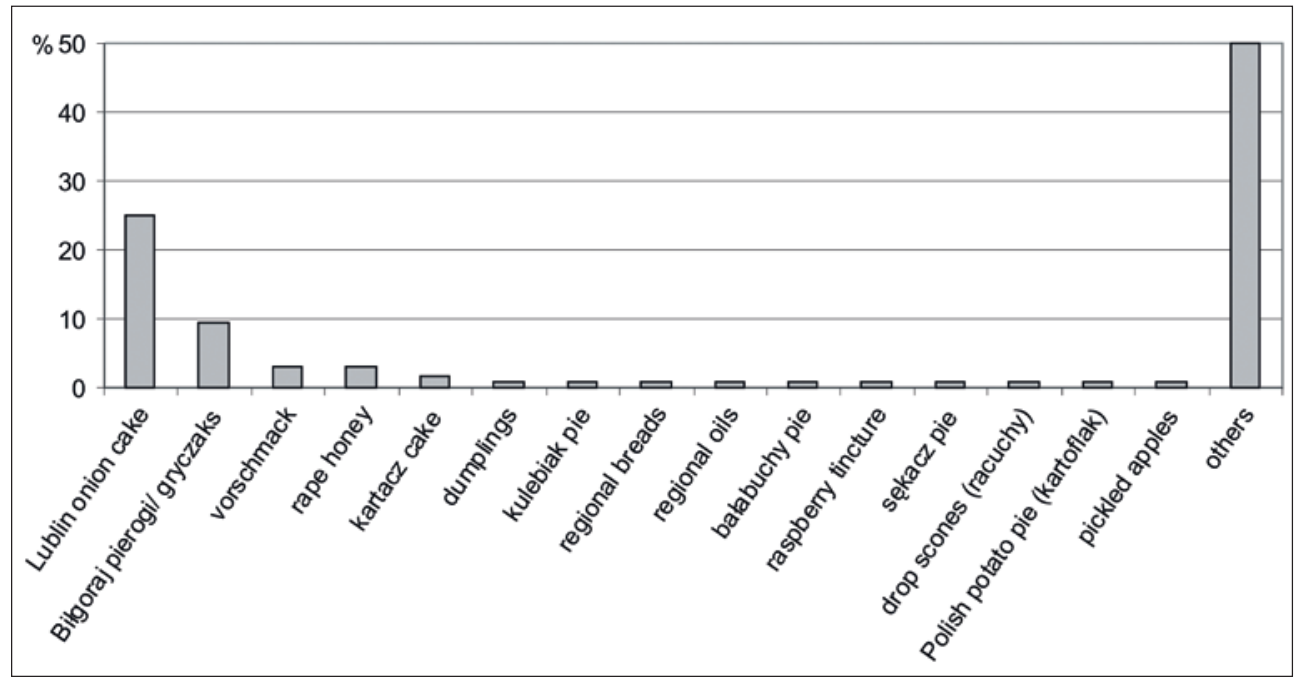

Fig. 14 Regional dishes and products mentioned by the respondents.

Source: Authors, based on own calculations and the questionnaire survey.

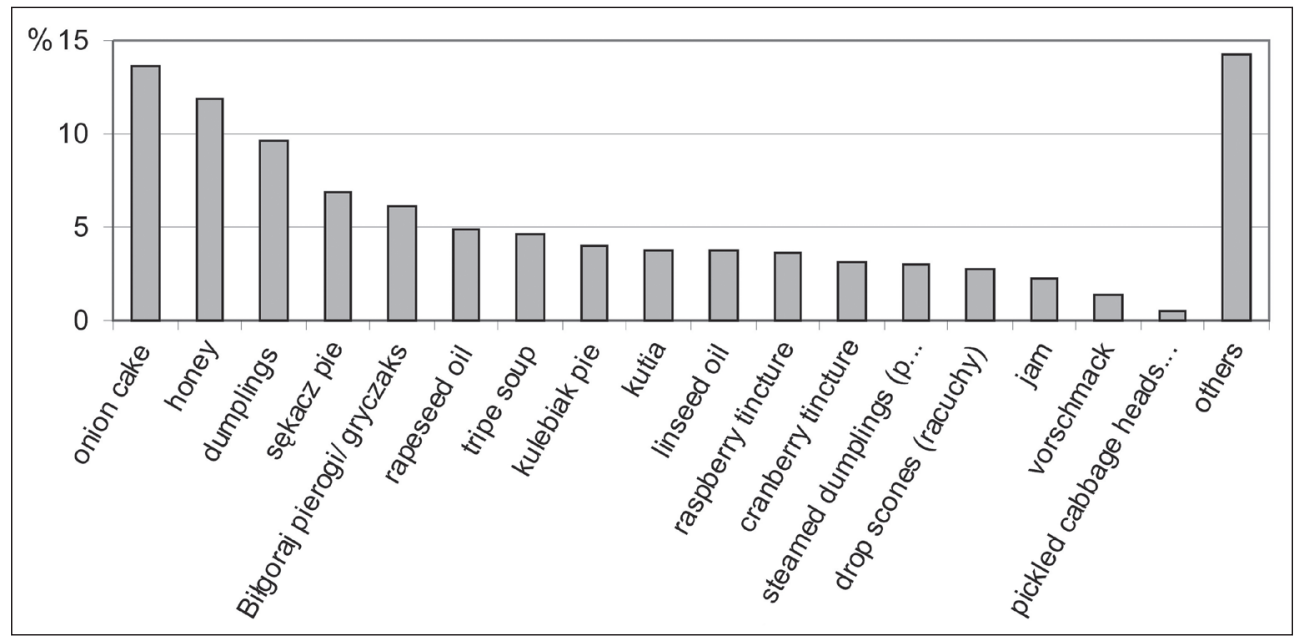

Fig. 15 Regional products and dishes associated by the respondents with Lubelskie Province.

Source: Authors, based on own calculations and the questionnaire survey. 
Biłgoraj pieróg (6.1\%), and rape or linseed oils (8.7\%), as well as tinctures - raspberry (malinówka) or cranberry (żurawinówka) (6.7\%). Other dishes, e.g. tripe soup (flaki), kulebiak pie, kutia, and steamed dumplings (parowańce) were less strongly associated with the region (Figure 15).

To sum up, the analysis presented above indicates that Lubelskie Province and the foodstuffs (including regional ones) produced in the region are recognisable in Poland. Similar observations were reported by Czeczelewski et al. (2017).

As shown by the research results, regional products appear to be important for creation of the tourist offer of Lublin Province, including culinary tourism. This is also confirmed by field observations, which demonstrate that there has been an increase in the interest in the offer of regional products expressed by both manufacturers and customers in recent years. Such dishes and products are increasingly being offered in the menu of gastronomic facilities. Additionally, regional food selling facilities are set up, especially in attractive rural areas. New events related to cultural heritage appear, during which dishes and regional products are offered and accompanied by workshops on their preparation. Moreover, traditional recipes are made available on websites.

Further development of tourism in the rural areas of Lubelskie Province should be accompanied by other promotional campaigns and protective activities, e.g. registering other products under the EU regional and traditional products protection scheme (e.g. gryczak/Biłgoraj pieróg, honeys, regional oils, and tinctures). Furthermore, besides products that are already offered in the region based on the culinary heritage (e.g. the Museum of Cebularz in Lublin, the Trail of the Tastes of the Land of Loess Gorges, the European Festival of Taste in Lublin, "Gryczaki" Groats Festival in Janów Lubelski), new products should be offered, such as food-producing establishments, gastronomy museums, culinary trails, events) with domestic and foreign tourists in mind.

\section{Potential of the use of traditional agricultural landscapes in the development of Lublin Province in relation to strategic documents}

Tourism development in peripheral rural areas may improve their economic situation by using the tangible and intangible rural resources, which has been demonstrated by the study results. Tourism has been proven to have an important role to play in this respect. Many researchers have already found sense in developing tourism activity, e.g. Tervo-Kankare, Tuohino (2016); Lane, Kastenholz (2015); Carneiro et al. (2015); Siow et al. (2013); Cawley, Gillmor (2008); Garrod et al. (2006). Tourism as a new function developed in rural areas has also been recommended in a number of strategic documents, including global and European-scope strategies (e.g. CEC 1996, 2005; OECD 1995, after Cawley, Gillmor 2008).

In Poland, such recommendations can also be found in many documents of national importance (e.g. in the Krajowa Strategia Rozwoju Regionalnego 2010-2020: Regiony, Miasta, Obszary Wiejskie, adopted in 2010; Koncepcja Przestrzennego Zagospodarowania Kraju 2030 (adopted in 2011); Strategia Rozwoju Kraju 2020 (approved in 2012); Strategia Rozwoju Kapitału Społecznego 2020 (since 2013); Program Rozwoju Turystyki na Obszarach Wiejskich (adopted in 2015). They foster tourism development by creating new jobs in the tourism industry and by taking action to improve tourist attractiveness of rural areas. Following the strategic assumptions, tourism development should involve building up infrastructure, protecting and promoting natural and cultural heritage and landscape, as well as increasing the creativity of local communities. This should result in using unique endogenous resources, developing local products and tourist services and, consequently, growing competitiveness of the region. Moreover, the activities should improve the quality of inhabitants' lives and tourists' comfort of stay and satisfaction, stemming from the features of the tourism space.

On the regional level (Strategia rozwoju województwa lubelskiego na lata 2014-2020, possibly continued until 2030, adopted in 2014; Plan Zagospodarowania Przestrzennego Województwa Lubelskiego, approved in 2015), it is recommended that tourism should be developed in rural areas, tourism institutions should be supported, and the region's offer should be promoted. The core of the activity should be tourist products - especially those related to cultural (including culinary) tourism, also in the supra-regional aspect (e.g. theme tourist trails), which should be next promoted in Poland and abroad. One of the ways to do it is applying for EU certificates for regional food products, such as Protected Geographical Indication (PGI), Protected Designation of Origin (PDO), or Traditional Speciality Guaranteed (TSG).

To sum up, as shown in the literature on the subject and the strategic documents presented above, it is possible to use traditional farming landscapes for development of Lubelskie Province by protection and promotion of the natural and cultural heritage, development of tourism in rural areas, maintenance of the high quality of the natural environment as a place to live for inhabitants and to visit for tourists, and building social capital (educating, raising qualifications, triggering creativity, and stimulating the inhabitants).

The observations made in Lubelskie Province seem to fit into the future scenarios for peripheral regions. In certain conditions, they may pass straight from the agrarian to the information technology civilization, omitting the industrial era on the way (Olechnicka 
2004; Gilowska et al. 2000). The prerequisite for this change is a high potential of the countryside resources (e.g. good quality of the natural environment, an attractive landscape, unique cultural heritage), which build the image of the region, as well as a high social capital (Siow et al. 2013; Garrod et al. 2006). Tourism developed in such conditions, integrating various actors (e.g. farmers, consumers, institutions) (Ilbery and Kneafsey 1999), may contribute to the improvement of the socio-economic situation of peripheral regions.

\section{Conclusions}

At present, there are many regions where traditional agricultural landscapes have survived. They are distinguished by specific socio-economic features, e.g. traditional extensive farming and production mainly for own needs or local markets. Frequently, such regions are referred to as peripheral. Due to the lack of other development opportunities, such areas are dominated by agricultural function with traditional crops and lifestyle. On the one hand, these characteristics determine the low income (poverty) of the inhabitants; on the other hand, they are a valuable component of the region's cultural heritage.

As shown by the literature, given the growing demand for authentic sensations and impressions, tourists are increasingly choosing areas/regions where elements of local heritage are preserved in various forms, e.g. local food and cuisine. They are perceived as important components of the overall experience of the destination.

Traditional food is therefore an attractive resource facilitating creation of a variety of tourist products (events, workshops, museums, routes, gastronomic facilities, agritourism farms) and providing the possibility of using the offer as a marketing tool. The level of marketing, entrepreneurship, and investments implemented by local communities and local governments will consequently determine the further development of the region in this respect.

The use of regional products can contribute to stimulation and support for traditional agricultural activity and maintenance of centuries-old food production methods, preservation of the authenticity of the place (sense of place), enhancement of the attractiveness of the region; empowering the community (e.g. by creating jobs, development of entrepreneurship); integration of residents by the sense of pride in the common heritage (especially in relation to food), and consequently to strengthening the identity of the region/ area brand (see also Telfer, Wall 1996). In the light of the research results, this also seems to be confirmed by the presented place of origin concept, as manufactured regional products consolidate the positive image of regions with traditional agricultural landscapes, simultaneously strengthening two brands - the product through the reputation of the place and the place - through the reputation of the product.

As shown by the present analyses and considerations, it is possible to develop another function, i.e. a touristic function, in the peripheral regions with traditional agricultural landscapes. However, it should be developed in a sustainable way as a supplementation of the basic agricultural function. Only such a way of using the region's resources will not diminish its authenticity, which determines its attractiveness.

Social capital is a very important factor in the activities described above, as the awareness, activity, and creativity of the inhabitants will determine their success in the future.

\section{References}

Adamczuk, F. (2013): Produkty tradycyjne i regionalne i ich wykorzystanie w promocji regionu. Prace Naukowe Uniwersytetu Ekonomicznego we Wrocławiu, Polityka Ekonomiczna, 307, 15-24.

Andéhn, M., Berg, P. O. (2011): Place of origin effects - From nations to cities: A conceptual framework based on a literature review, Presented at the 2nd INPOLIS - 2nd International Place Branding Conference, Bogotá, 1-24.

Bański, J. (2010): Atlas Rolnictwa Polski. Warszawa, Instytut Geografii i Przestrzennego Zagospodarowania PAN.

Bekier-Jaworska, E., Bochenek, M. (2014): Brandt products of regional cuisine in the promotion of tourism in Roztocze. Polish Journal of Sport and Tourism 21(4), 263-272, https://doi.org/10.1515/pjst-2015-0007.

Bessiére, J. (1998): Local Development and Heritage: Traditional Food and Cuisine as Tourist Attractions in Rural Areas. Sociologia Ruralis 38(1), 21-34, https:// doi.org/10.1111/1467-9523.00061.

Bessiére, J., Tibere, L. (2013): Traditional Food and Tourism: French Tourist Experience and Food Heritage in Rural Spaces. Journal of the Science of Food and Agriculture 93(14), 3420-3425, https://doi.org/10.1002/jsfa.6284.

Boniface, P. (2003): Tasting Tourism: Travelling for Food and Drink. Hampshire: Ashgate.

Borowska, A. (2010): The role of traditional and regional food products in rural development in Poland. Social Research 18 (1), 40-52.

Bronisz, U., Dymek, Z., Jakubowski, A., Tucki, A. (2017): Potencjał turystyczny województwa lubelskiego w 2015 roku. Analizy statystyczne. Lublin, Urząd Statystyczny w Lublinie.

Brown, J., Kothari, A. (2011): Traditional agricultural landscapes and community conserved areas: an overview. Management of Environmental Quality: An International Journal 22(2), 139-153, https:// doi.org/10.1108/14777831111113347.

Bruwer, J., Lesschaeve, I. (2012): Wine tourists' destination region brand image perception and antecedents: Conceptualization of a winescape framework. Journal of Travel and Tourism Marketing 29, 611-628, https:// doi.org/10.1080/10548408.2012.719819.

Carneiro, M. J., Lima, J., Silva, A. L. (2015): Landscape and the rural tourism experience: identifying key elements, addressing potential, and implications for the future. 
Journal of Sustainable Tourism 23(8-9), 1217-1235, https://doi.org/10.1080/09669582.2015.1037840.

Cawley, M., Gillmor, D. A. (2008): Integrated rural tourism: concepts and practice Annals of Tourism Research 35(2), 316-337, https://doi.org/10.1016/j.annals.2007.07.011.

Charters, S., Spielmann, N., Babin, B. J. (2017): The nature and value of terroir products. European Journal of Marketing 51(4), 748-771, https://doi.org/10.1108 /EJM-06-2015-0330.

Cohen, E., Avieli, N. (2004): Food in tourism. Annals of Tourism Research, 31, 4, 755-778, https://doi.org /10.1016/j.annals.2004.02.003.

Corigliano, M. A. (2002): The route to quality: Italian gastronomy networks in operation. [In:] A. Hjalager, G. Richards (eds.) Tourism and Gastronomy. London: Routledge, 166-185.

Crouch, G. I., Ritchie, J. R. B. (1999): Tourism, competitiveness and social prosperity. Journal of Business Research 44, 137-152, https://doi.org /10.1016/S0148-2963(97)00196-3.

Czeczelewski, J., Tucki, A., Czeczelewska, E. (2017): The use of cluster analysis in the research on shopping preferences regarding regional products from lubelskie voivodeship. Journal of Agribusiness and Rural Development 43(1), 57-67, https://doi.org/10.17306 /J.JARD.2017.00319

Fischer, J., Hartel, T., Kuemmerle, T. (2012): Conservation policy in traditional farming landscapes. Conservation Letters 5(3), 167-175, https://doi.org /10.1111/j.1755-263X.2012.00227.x.

Flaga, M. (2018): Model przemian demograficznych w regionach wyludniających się Polski na przykładzie województwa lubelskiego. Lublin, Wydawnictwo UMCS.

Garrod, B., Wornell, R., Youell, R. (2006): Re-conceptualising rural resources as countryside capital: The case of rural tourism. Journal of Rural Studies 22, 117-128, https:// doi.org/10.1016/j.jrurstud.2005.08.001.

Gilowska, Z., Gorzelak, G., Jałowiecki, B., Sobczak, K. (2000): Kierunki polityki regionalnej Polski. Warszawa, EUROREG.

Hall, C. M., SHarples, L., Mitchell, R., Macionis, N., Cambourne, B. (eds.) (2003): Food Tourism Around the World. Oxford: Butterworth Heinemann.

Hankinson, G. (2004): Relational network brands: Towards a conceptual model of place brands. Journal of Vacation Marketing 10(2), 109-121, https://doi.org/10.1177 /135676670401000202.

Hjalager, A., Richards, G. (eds.) (2002): Tourism and Gastronomy. London: Routledge, https://doi.org /10.4324/9780203218617.

Ilbery, B., Kneafsey, M. (1999): Niche markets and regional speciality food products in Europe: Towards a research agenda. Environment and Planning A 31, 2207-2222, https://doi.org/10.1068/a312207.

Ivanova, L., Terziyska, I., Trifonova, J. (2014): Characteristics of traditional food - the viewpoint of the tourism business. Zeszyty Naukowe Uniwersytetu Szczecińskiego. Scientific Journal. Service Management 14, 123-130.

Jansen-Verbeke, M., Mckercher, B. (2013): Reflections on the Myth of Tourism Preserving "Traditional" Agricultural Landscapes, Journal of Resources and Ecology 4 (3), 242-249, https://doi.org/10.5814/j.issn.1674-764x 2013.03.007.
Koncepcja Przestrzennego Zagospodarowania Kraju 2030 Załącznik do uchwały nr 239 Rady Ministrów z dnia 13 grudnia 2011 r. (poz. 252). Monitor Polski, Dziennik Urzędowy Rzeczypospolitej Polskiej, Warszawa, dnia 27 kwietnia 2012 r., http://prawo.sejm.gov.pl/isap.nsf /download.xsp/WMP20120000252/0/M20120252-1 .pdf.

Kowalczyk, A. (2016): Turystyka kulinarna - podejścia 'geograficzne' i 'niegeograficzne'. Turystyka Kulturowa, www.turystykakulturowa.org, 5, 29-59.

Krajowa Strategia Rozwoju Regionalnego 2010-2020: Regiony, Miasta, Obszary Wiejskie. Dokument Przyjęty Przez Radę Ministrów dnia 13 lipca 2010 r. Ministerstwo Rozwoju Regionalnego, Warszawa.

Lai, M. Y., Khoo-Lattimore, C., Wang, Y. (2017): Food and cuisine image in destination branding: Toward a conceptual model, Tourism and Hospitality Research 19(2), 238-251, https://doi.org/10.1177 /1467358417740763.

Lane, B., Kastenholz, E. (2015): Rural tourism: the evolution of practice and research approaches: towards a new generation concept? Journal of Sustainable Tourism 23(8-9), 1133-1156, https://doi.org/10.1080/0966958 2.2015.1083997.

Lentz, P., Holzmüller, H. H., Schirrmann, E. (2006): City-oforigin effects in the German beer market: transferring an international construct to a local context. Advances in International Marketing 17, 251-274, https://doi.org /10.1016/S1474-7979(06)17009-X.

Lin, Y. C., Pearson, T. E., Cai, L. A. (2011): Food as a form of destination identity: A tourism destination brand perspective. Tourism and Hospitality Research 11(1), 30-48, https://doi.org/10.1057/thr.2010.22.

Long, L. (ed.) (2003): Culinary Tourism: Food, Eating and Otherness. Lexington: University of Kentucky Press.

Lorenz, B. A., Hartmann, M., Simons, J. (2015): Impacts from region-of-origin labeling on consumer product perception and purchasing intention - Causal relationships in a TPB based model. Food Quality and Preference 45, 149-157, https://doi.org/10.1016 /j.foodqual.2015.06.002.

Macdonald, H. S. (2001): National tourism and cuisine forum: 'Recipes for Success'. Canadian Tourism Commission.

Marcoz, E. M., Melewar, T. C., Dennis, C. (2016): The value of region of origin, producer and protected designation of origin label for visitors and locals: The case of Fontina cheese in Italy. International Journal of Tourism Research 18(3), 236-250, https://doi.org/10.1002 /jtr.2000.

Mazur, M., Bański, J., Czapiewski, K., Śleszyński, P. (2015): Przemiany struktury przestrzennej i funkcjonalnej obszarów wiejskich w Polsce. Studia obszarów wiejskich 37, 7-36, https://doi.org/10.7163/SOW.37.1.

Michoń, D., 2017. Zróżnicowanie rozwoju społecznogospodarczego województw ze względu na realizację celów polityki spójności. Wiadomości Statystyczne 12(679), 80-94.

Milewska, M., Prączko, A., Stasiak, A. (2017): Podstawy gastronomii. Od żywności do turystyki kulinarnej, Warszawa, PWE.

Miszczuk, A. (2010): Peryferyjność regionów. [In:] A. Tucholska (ed.), Europejskie wyzwania dla Polski i jej regionów, Warszawa, MRR, 236-250. 
Okumus, B., Cetin, G. (2018): Marketing Istanbul as a culinary destination, Journal of Destination Marketing \& Management 9, 340-346, https://doi.org/10.1016 /j.jdmm.2018.03.008

Olechnicka, A. (2004): Regiony peryferyjne w gospodarce informacyjnej. Warszawa Wydawnictwo Naukowe Scholar.

Orłowski, D. (2016): Kuchnia regionalna i jej wykorzystanie w rozwoju turystyki kulinarnej na Lubelszczyźnie. [In:] G. Godlewski, J. Roszak (eds.), Niematerialne i materialne dziedzictwo Lubelszczyzny jako podstawa rozwoju turystyki kulturowej. Warszawa, Instytut Slawistyki Polskiej Akademii Nauk, 83-95.

Peterson, R. A., Jolibert, A. J. P. (1995): A Meta-Analysis of Country-of-Origin Effects. Journal of International Business Studies 26(4), 883-900, https://doi.org /10.1057/palgrave.jibs.8490824.

Plan Zagospodarowania Przestrzennego Województwa Lubelskiego. Zał. nr 1 do Uchwały Nr XI/162/2015 Sejmiku Województwa Lubelskiego z dnia 30 października 2015 r. https://umwl.bip.lubelskie.pl /upload/pliki//2Zal.1_tekst_PZPWL.pdf.

Powierzchnia i ludność w przekroju terytorialnym w 2018 r. Area and population in the territorial profile in 2018. Statistics Poland, Warsaw. Online: https://stat.gov.pl/ obszary-tematyczne/ludnosc/ludnosc/powierzchnia-iludnosc-w-przekroju-terytorialnym-w-2018-roku,7,15. html (accessed 10 July 2018).

Program Rozwoju Turystyki na Obszarach Wiejskich w Polsce. Polska Federacja Turystyki Wiejskiej „Gospodarstwa Gościnne”. Warszawa, 2015.

Richards, G. (2002): Gastronomy: An essential ingredient in tourism production and consumption? [In:] A. Hjalager, G. Richards (eds.) Tourism and Gastronomy. London: Routledge, 2-20.

Richards, G. (2015): Evolving gastronomic experiences: From food to foodies to foodscapes. Journal of Gastronomy and Tourism 1(1), 5-17, https://doi.org /10.3727/216929715X14298190828796.

Rolnictwo w województwie lubelskim w 2016 r. Informacje i Opracowania Statystyczne. Urząd Statystyczny w Lublinie, Lublin, 2017.

Scarpato, R. (2002): Gastronomy as a tourist product: the perspective of gastronomy studies. [In:] A. Hjalager, G. Richards (eds.) Tourism and Gastronomy. London: Routledge, 51-70.

Schooler, R. D. (1965): Product bias in the Central American Common Market. Journal of Marketing Research 2, 394-397, https://doi.org/10.1177 /002224376500200407.

Selfa, T., Fish, R., Winter, M. (2010): Farming livelihoods and landscapes: Tensions in rural development and environmental regulation. Landscape Research 35(6), 595-612. https://doi.org/10.1080/01426397.2010.51 4043.

Sims, R. (2009): Food, place and authenticity: local food and the sustainable tourism experience. Journal of Sustainable Tourism 17(3), 321-336, https://doi.org /10.1080/09669580802359293.

Siow, M. L., Ramachandran, S., Shuib, A., Nair, M., Afandi, S. H. M., Sudesh, P. (2013): Rural resources as tourism capital: the case of Setiu Wetlands, Terengganu, Malaysia. The Malaysian Forester 76(1), 27-39.
Skoczylas, K. (2012): Promocja i kreowanie wizerunku regionu na podstawie kampanii promocyjnych województwa lubelskiego. [In:] R. Krukowska (ed.), Turystyczne, rekreacyjne i geograficzne aspekty kształtowania przestrzeni. Lublin, Karpol s.c.

Skowronek, E., Krukowska, R., Świeca, A., Tucki, A. (2005): The evolution of rural landscapes in mid-eastern Poland as exemplified by selected villages. Landscape and Urban Planning 70, 45-56, https://doi.org/10.1016 /j.landurbplan.2003.10.004.

Skowronek, E., Wojciechowski, K. H., Świeca, A. (2006): The history of the ethnic transformations of the Lublin Region. [In:] E. Skowronek, W. Wołoszyn, T. Speck, K. M. Born (eds.), Cultural Landscapes of the Lublin Upland and Roztocze. Lublin, Kartpol s.c., 33-47.

Solon, J., Borzyszkowski, J., Bidłasik, M., Richling, A., Badora, K., Balon, J., Brzezińska-Wójcik, T., Chabudziński, Ł., Dobrowolski, R., Grzegorczyk, I., Jodłowski, M., Kistowski, M., Kot, R., Krąż, P., Lechnio, J., Macias, A., Majchrowska, A., Malinowska, E., Migoń, P., Myga-Piątek, U., Nita, J., Papińska, E., Rodzik, J., Terpiłowski, S., Ziaja, W. (2018): Physico-geographical mesoregions of Poland - verification and adjustment of boundaries on the basis of contemporary spatial data. Geographia Polonica 91(2), 143-170, https://doi.org /10.7163/GPol.0115.

Spilková, J., Fialová, D. (2013): Culinary tourism packages and regional brands in Czechia. Tourism Geographies 15(2), 177-197, https://doi.org/10.1080/14616688 .2012.726268.

Špulerová, J., Bezák, P., Dobrovodská, M., Lieskovský, J., Štefunková, D. (2017): Traditional agricultural landscapes in Slovakia: why should we preserve them? Landscape Research 48(2), 891-903, https://doi.org /10.1080/01426397.2017.1385749.

Stasiak, A. (2015): Rozwój turystyki kulinarnej w Polsce. [In:] B. Krakowiak, A. Stasiak (eds.), Kultura i turystyka - wokół wspólnego stołu. Łódź, Regionalna Organizacja Turystyczna Województwa Łódzkiego, 119-150.

Strategia Rozwoju Kapitału Społecznego 2020. Załącznik do uchwały nr 61 Rady Ministrów z dnia 26 marca 2013 r. (poz. 378). Monitor Polski, Dziennik Urzędowy Rzeczypospolitej Polskiej, Warszawa, dnia 16 maja $2013 \mathrm{r}$.

Strategia Rozwoju Kraju. 2020. Dokument przyjęty uchwałą Rady Ministrów w dniu 25 września 2012 roku. Ministerstwo Rozwoju Regionalnego, Warszawa.

Strategia rozwoju województwa lubelskiego na lata 2014-2020 (z perspektywą do 2030 r.). Urząd Marszałkowski Województwa Lubelskiego w Lublinie. Lublin, 2014.

Szczęsna, J., Gawrysiak, L. (2009): Wielokulturowe dziedzictwo Lubelszczyzny elementem potencjału turystycznego regionu. Annales UMCS, sec. B 64(1), 37-52, https://doi.org/10.2478/v10066-008-0017-6.

Świeca, A., Brzezińska-Wójcik, T. (2009): Regional diversity of river basin geosystems of mid-eastern Poland in the light of solute flow studies. Prace i Studia Geograficzne 41, 205-218.

Telfer, D., Wall, G. (1996): Linkages between tourism and food production. Annals of Tourism Research 23, 635-653, https://doi.org/10.1016/0160-7383(95) 00087-9. 
Tervo-Kankare, K., Tuohino, A. (2016): Defining 'rurality' for rural wellbeing tourism - Halfacree's conceptual triad of the production of rural space in practical-level tourism development in Northern Europe. Nordia Geographical Publications 45(2), 37-52.

Turski, R., Uziak, S., Zawadzki, S. (2008): Gleby. [In:] S. Uziak, R. Turski (eds.), Środowisko przyrodnicze Lubelszczyzny. Lublin, Lubelskie Towarzystwo Naukowe, 211-315.

Urry, J. (1990): The tourist gaze: Leisure and travel in contemporary societies. London: Sage.

Usunier, J. C. (2006): Relevance in business research: the case of country-of-origin research in marketing. European Management Review 3(2006), 60-73, https://doi.org/10.1057/palgrave.emr.1500049.
Winawer, Z., Wujec, H. (2010): Tradycyjne i regionalne produkty wysokiej jakości we wspólnej polityce rolnej. Poradnik dla producentów. Warszawa, Fundacja dla Polski.

Wolf, E. (2002): Culinary tourism: A tasty economic proposition. Portland, International Culinary Tourism Task Force.

Vafadari, K. (2013): Planning sustainable tourism for agricultural heritage landscapes. Ritsumeikan Journal of Asia Pacific Studies 32, 75-89.

https://www.lubelskie.pl/kampanie-promocyjne (accessed 10 October 2018)

https://www.gov.pl/rolnictwo/lista-produktow -tradycyjnych12 (accessed 12 January 2019) 